Agro-Science Journal of Tropical Agriculture, Food, Environment and Extension Volume 11 Number 1 January 2012 pp $1-9$

ISSN 1119-7455

\title{
STRUCTURAL STABILITY AND HYDRAULIC CONDUCTIVITY OF NKPOLOGU SANDY LOAM SOIL UNDER DIFFERENT LAND COVERS IN SOUTHEASTERN NIGERIA.
}

\author{
Azuka C.V. and Obi M.E. \\ Department of Soil Science, University of Nigeri, Nsukka.
}

\begin{abstract}
Studies were conducted in the runoff plots at the University of Nigeria Nsukka Teaching and Resesarch Farm in 2010 and 2011 to monitor the changes in structural stability and saturated hydraulic conductivity (Ksat) of Nkpologu sandy loam soil under different cover management practices. The management practices were bare fallow (BF), grass fallow $(G F)$, legume (CE), groundnut $(G N)$, sorghum (SM), and cassava (CA) cultivation. Three samplings were carried out at the study site following the characterization of the soil at five- month interval marking the end of first cropping season, and the start and end of the second cropping season respectively. There was no change in soil texture due to treatments. The aggregate stability (AS), mean weight diameter (MWD), water dispersible silt (WDSi), aggregate size distributions (> $2 \mathrm{~mm}, 1-0.5 \mathrm{~mm}$ and $<0.25 \mathrm{~mm})$ and Ksat showed significant $(P=0.05)$ changes with time. Ksat varied $(C V=52 \%)$ significantly $(P=0.05)$ with a standard deviation $(S D)$ value of 7.8. The highest values for Ksat, AS and $M W D$ were obtained in the first sampling period whereas the lowest values were obtained in the last sampling period. There were significant effect $(P=0.05)$ of cover management practices on $A S, M W D$ and Ksat. The highest values for AS, MWD and aggregate size fraction $>2 \mathrm{~mm}$ were obtained under GF whereas the highest Ksat was obtained under GN. The lowest values for these parameters throughout the sampling periods were obtained under $B F$. The preponderance of aggregates $<0.5 \mathrm{~mm}$ under $B F$ showed that raindrop impact and other agents broke down macroaggregates into microaggregates. The cover treatments generally increased organic matter (O.M.) content compared with the BF. The O.M. had significant correlation with two aggregate size ranges; $1-0.5 \mathrm{~mm}\left(r=-0.276^{*}\right.$ at $\left.P=0.05\right)$ and $0.5-0.25 \mathrm{~mm}\left(r=-0.245^{*}\right.$ at $\left.P=0.05\right)$. The study has shown that cover management practices affected the structural properties of the tropical sandy loam soil differently over time.
\end{abstract}

Keywords: Aggregate stability, MWD, aggregate size distribution, macroaggregates, microaggregates, saturated hydraulic conductivity, Cover management.

\section{INTRODUCTION}

Soil productivity and sustainability depend on dynamic equilibrium among the physical, chemical and biological properties. Evaluating the impact of agricultural practices on agroecosystems functions is essential for determining the sustainability of such systems (Liebig et al, 2001). Under natural condition, soil physico-chemical properties deteriorate very slowly. Structural deterioration occurs as a result of intensive land use. Soil structure is the physical characteristic most vulnerable to soil management practices. Structure exerts important influences on the functioning of soil, its ability to support plant and animal life, and its control on environmental quality. A common index of soil structure - the degree of stability of aggregates, moderates physical, chemical, and biological processes leading the soil dynamics (Bronick and Lal, 2005). Maintenance of high aggregate stability in soils is desirable for sustainable land use as it is essential for the preservation of agricultural production, minimizing soil erosion and degradation and reducing environmental pollution (Amezketa 1999). A reduction in soil aggregate stability implies an increase in soil degradation. Oti (2002) reported a decline in water stable aggregates which makes soils unstable to raindrop impact thereby enhancing disintegration and slaking. The factors that influence aggregate stability of tropical soils depend on the soil environment, the type and dominance of the stabilizing substances and land use (Mbagwu, 2003). Soil structure and consequently soil hydraulic properties of tilled soil varied in space and time (Strudley et al., 2008). The temporal variation of the soil hydraulic properties (mainly hydraulic conductivity, $K$ ) have been well investigated for instance in following studies (Murphy et al., 1993, 
Messing and Jarvis, 1993, Somaratne and Smettem 1993). The temporal variability of the soil aggregate stability has been studied (Chan et al. 1994, Yang and Wander 1998). Chan et al. (1994) documented that temporal changes of aggregate stability were not positively related to living root length /density. Many studies have been carried out on aggregate stability and hydraulic properties (mainly saturated hydraulic conductivities, Ksat) of soil especially in the temperate region but less attention has been given to their temporal variations especially in tropical regions. A good knowledge of seasonal changes in soil structural stability and saturated hydraulic conductivity is essential for optimal and sustainable management of our agroecosystem. The objective of this study was to investigate the changes in structural stability and hydraulic conductivity of a sandy loam soil under different cover management systems.

\section{MATERIALS AND METHODS Site description}

The study was carried out at the University of Nigeria Nsukka Teaching and Research Farm located between latitude $06^{\circ} 52^{\prime} \mathrm{N}$ and longitude $07^{\circ} 24^{\prime} \mathrm{E}$ on runoff plots established in 1973. The area is characterized by a humid tropical climate with wet and dry season (Obi, 1982). The rainfall is bimodally distributed with annual total of about $1750 \mathrm{~mm}$. The average annual rainfall erosivity $(\mathrm{R})$ estimated by the method of Roose (1977) is 800. The mean annual temperature is $27^{\circ} \mathrm{C}$ with minimum and maximum of $21^{\circ} \mathrm{C}$ and $31^{\circ} \mathrm{C}$ respectively (UNN meteorological station).

The runoff plots, each $20 \times 3 \mathrm{~m}$, were located on a $5 \%$ slope with mean elevation of $400 \mathrm{~m}$ above sea level. The plots were used to monitor variations in aggregate stability and hydraulic properties of soils under different soil/crop management practices. The soil is an Ultisol (Acrisol, FAO; sol ferrallitique, French system) belonging to the Nkpologu series. It is deep, porous, and red to brownish red and derived from sandy deposit of false bedded sand stones, classified as Typic Paleustult (Nwadialo, 1989).

\section{Field methods/ crop establishment}

The experimental layout was a completely randomized design (CRD) and the treatments imposed were replicated four times. Cassava, groundnuts, sorghum and centrosema were used as test crops. The test crops were grown with 10 tons/ha poultry droppings during crop establishment in 2010, while the bare fallow and grass fallow remained untilled with no amendment. Groundnut seeds were sown at a rate of two seeds per hole and at a planting distance of $45 \mathrm{~cm}$ by $30 \mathrm{~cm}$. Sorghum seeds were sown at the rate of four seeds per hole at a planting distance of $70 \mathrm{~cm}$ by $30 \mathrm{~cm}$ and later reduced to two. Cassava cuttings of length $25 \mathrm{~cm}$ was planted $15 \mathrm{~cm}$ deep into the soil at a rate of one cutting per hole and at a planting distance of $1 \mathrm{~m}$ by $1 \mathrm{~m}$. The Centrosema seeds were established by broadcasting the seeds on the soil surface after tillage and fresh supplies were made in areas where germination failed to occur. Groundnut and sorghum were harvested at five and six months after planting respectively. Cassava was harvested at twelve months after planting while centrosema was not harvested.

\section{Measurement of soil physical properties}

On each of the test plots, undisturbed soil core samples, each $5.0 \mathrm{~cm}$ (diameter) by $5.5 \mathrm{~cm}$ (length) for determination of hydraulic conductivity was collected randomly from the top soil $(0-15 \mathrm{~cm})$. Soil sample for aggregate stability determination was collected at the depth of $0-15 \mathrm{~cm}$ in each site, air dried, and sieved through a $4.75 \mathrm{~mm}$ mesh. Samples retained on the $2 \mathrm{~mm}$ sieve were used for aggregate stability determination while those that passed through the $2 \mathrm{~mm}$ sieve were used to determine particle size distribution and organic matter content.

\section{LaboratoryMethod}

The particle size distribution of was determined by the hydrometer method as described by Gee and Bauder (1986) using sodium hexametaphosphate (calgon) for the dispersion. Organic carbon was determined according to the method described by Nelson and Sommers (1982). The organic matter content was obtained by multiplying values obtained for organic carbon by a factor of 1.72. Saturated hydraulic conductivity (Ksat) was evaluated by the constant head method. The transposed Darcy's equation, as outlined by Young (2001) was used for the computation of Ksat.

Ksat $=$ QL/AT $\Delta \mathrm{H}$

where $\mathrm{Q}=$ steady state volume of outflow from the entire soil column $\left(\mathrm{cm}^{3}\right), \mathrm{L}$ is the length of soil column $(\mathrm{cm}), \mathrm{A}$ is the cross-sectional area of the soil column $\left(\mathrm{cm}^{2}\right), \Delta \mathrm{H}$ is the change in hydraulic head or the head pressure difference causing the flow $(\mathrm{cm}), \mathrm{T}$ is the time of flow (seconds).

\section{Separation of water-stable aggregates}

The method described by Kemper and Rosenau (1986) was used to separate water-stable aggregate (WSA). In this method, $25 \mathrm{~g}$ of the $<4.75 \mathrm{~mm}$ airdried soil sample was placed in the topmost of a nest of sieves of 2.00, 1.00, 0.50, and $0.25 \mathrm{~mm}$ mesh sizes and pre-soaked for 5 minutes. Thereafter, the nest of sieves was oscillated vertically in water using $4-\mathrm{cm}$ amplitude at the rate of one oscillation /seconds. After wet sieving, the resistant soil materials on each sieve and the unstable $(<0.25 \mathrm{~mm})$ aggregates were transferred into clean beakers, oven-dried for 48 hours and weighed. Aggregate size distribution (ASD) was estimated and recorded as percentages of the original mass as shown;

$\mathrm{WSA}=(\mathrm{Mr} / \mathrm{Mt}) \times 100$-------------- (2) 
Where $\mathrm{Mr}$ is mass of resistant aggregates and $\mathrm{Mt}$ is the total mass of wet-sieved soil. The WSA was categorized into size ranges, namely $4.75-2.00$, $2.00-1.00,1.00-0.50,0.50-0.25$, and $<0.25 \mathrm{~mm}$. Mean weight diameter (MWD) of WSA was calculated as

$$
\text { MWD }=\sum \text { xiwi }
$$

$$
\mathrm{I}=1
$$

where $\mathrm{Xi}$ is the mean diameter of each sieve (mm) size or fraction and, $\mathrm{Wi}$ is the proportion of total sample weight in the corresponding size fraction.

\section{WSA > 0.5 mm (Aggregate stability)}

Aggregates fractions of $0.5 \mathrm{~mm}$ and above were poured into an evaporating dish and saturated with sodium hexametaphosphate (Calgon). Enough water was added to cover the aggregates and left for 24 hours for complete dispersion. The dispersed aggregates were washed through $0.5 \mathrm{~mm}$ sieve to remove all sand larger than $0.5 \mathrm{~mm}$. The sand was washed into an evaporating dish and dried in the oven for at least 2 hours after decanting the water, and weighed. Aggregate stability (AS) was calculated thus;

\section{WSA $>0.5 \mathrm{~mm}(\mathrm{AS})=[$ weight of WSA $>0.5 \mathrm{~mm}-$ weight of sand]/[Total mass of the sample-weight of sand]}

\section{Statistical Analysis}

The analysis of variance (ANOVA) for a completely randomized design (CRD) was carried out using a Genstat Discovery Edition version 5.0 (GENSTAT, 2003) on windows 7 and the mean difference of the effects of different crop growth on aggregate stability and hydraulic conductivity was compared using the least significant difference $\left(\mathrm{LSD}_{0.05}\right)$ as described by Obi (2002).

\section{RESULTS AND DISCUSSIONS}

\section{Texture and Organic matter content}

The texture and organic matter contents at the beginning and end of the experiment in 2010 and 2011 respectively are shown in Tables 1 and 2 . The textural class of the soil of the study area (sandy loam) remained unchanged under the different cover management practices. The varied cover management practices did not alter the texture of the soil due to the fact that texture is mainly a function of the nature of parent material. Nnabude (1986) gave a similar report on Nkpologu sandy loam soil. The dominance of the sand fraction is attributable to the dominant influence of the parent material which, in this case, is false-bedded sandstone. Investigations by Obi and Asiegbu (1980) in soils of similar parent material, showed predominance of sand fraction, irrespective of the system of farming adopted at the various sites.The highest organic matter contents $(1.46 \%$ and $1.34 \%)$ of the surface soil $(0-20 \mathrm{~cm})$ at the start of the experiment in 2010 were obtained under the Centrosema pascuorum and Panicum maximum treatments (Table 1). The least average value $(0.87 \%)$ was obtained under the Sorghum almun treatments contrary to the report by Obi and Nnabude (1987). This is because the site had been under fallow since 2006 till 2009 prior to this study in 2010 or due to the previous management practice introduced on Sorghun almun plot. The organic matter content of the bare fallow treatment was apparently influenced by the period of fallow but decreased subsequently during the period of the conduct of the experiment from $1.21 \%-0.78 \%$ while that of Sorghum almun improved appreciably at the end of the experiment in 2011 as shown in Table 2. The trend of the decrease and increase in organic matter content under different cover management practices is shown in Figure 1. Organic matter improved at the start of the second cropping season under groundnut plot but decreased at the end of the second cropping season. Organic matter content increased throughout the sampling period under grass fallow whereas the reverse was the case under cassava and bare fallow. Thus, the variation in organic matter content may not be attributed to cover management practice alone but also to cover type. The organic matter content remained lowest in the bare fallow plot throughout the sampling period which is a clear indication of the effect of clean clearing on soil organic matter storage.

\section{Aggregate Stability and size distribution}

There is significant effect of cover management practices on aggregate stability throughout the sampling period (Table 4). The highest value $(82.1 \%)$ was obtained in the first sampling date while the least value was obtained in the last sampling date. Veronika et al., (2010) observed temporal variations among sampling dates for most soil attributes. The bare fallow plot remained lowest throughout the sampling period. There is significant $(p=0.05)$ effect of cover management practices on aggregate stability (Table 3). Aggregate stability was highest $(80.3 \%)$ under the grass fallow and lowest $(51.2 \%)$ under the bare fallow plot. There was appreciable difference in aggregate stability due to grass cover compared to other cover management practices but the variability in aggregate stability within the cover management practices was low as seen from the values of standard deviation (16) and the CV (13.4\%). The significant effect of cover management practices could be attributed to root activity rather than organic matter (Veronika et al., 2010). They observed that soil aggregate stability depended on stage of the root zone development and in all cases, aggregate stability increased during the root growth. Six et al., 2002 noted that with low organic matter inputs, aggregates could become stabilized through the physical action of living roots and subsequently increase their stability. Aggregate size fraction $>2$ $\mathrm{mm}$ predominate in all the cover management 
practices applied except under bare fallow where aggregates $<1 \mathrm{~mm}$ predominate. Aggregate size fractions except $2-1 \mathrm{~mm}$ size fractions were significantly $(P=0.05)$ influenced by cover management practices. Canton et al., (2009) found significant effect of vegetation on $2-1 \mathrm{~mm}$ aggregate size range in a sandy loam soil in Spain, similar result was obtained by Bricchi (2003) in Argentina under different tillage systems. There is preponderance of aggregates $<1 \mathrm{~mm}$ in the bare fallow plot (Fig 2). Table 4 reveals that the cover management practices significantly $(\mathrm{P}=0.05)$ influenced aggregate size fractions $>2 \mathrm{~mm}, 1-0.5 \mathrm{~mm}$ and $<0.25 \mathrm{~mm}$ over the sampling periods. The variations in aggregate size distribution was more noticeable in $>2 \mathrm{~mm}(\mathrm{CV}=30.4 \%), 0.5-0.25 \mathrm{~mm}$
$(\mathrm{CV}=27.2 \%)$ and $<0.25 \mathrm{~mm} \quad(\mathrm{CV}=27.1 \%)$ respectively compared to $1-0.5 \mathrm{~mm}(\mathrm{CV}=23 \%)$ and $(\mathrm{CV}=21.8 \%)$ aggregate size ranges irrespective of their standard deviations.

The MWD was significantly $(P=0.05)$ affected by the different cover management practices. The highest value (2.22) was obtained under the grass fallow while the bare fallow plot recorded the lowest value (1.18). Higher values of MWD indicate the dominance of large aggregates of the soil which are less erodible (Piccolo et al., 1997). Thus, bare fallow plot is most prone to soil loss compared to other cover management practices as it is exposed to raindrop impact which breakdown less erodible large aggregates to more erodible microaggregates.

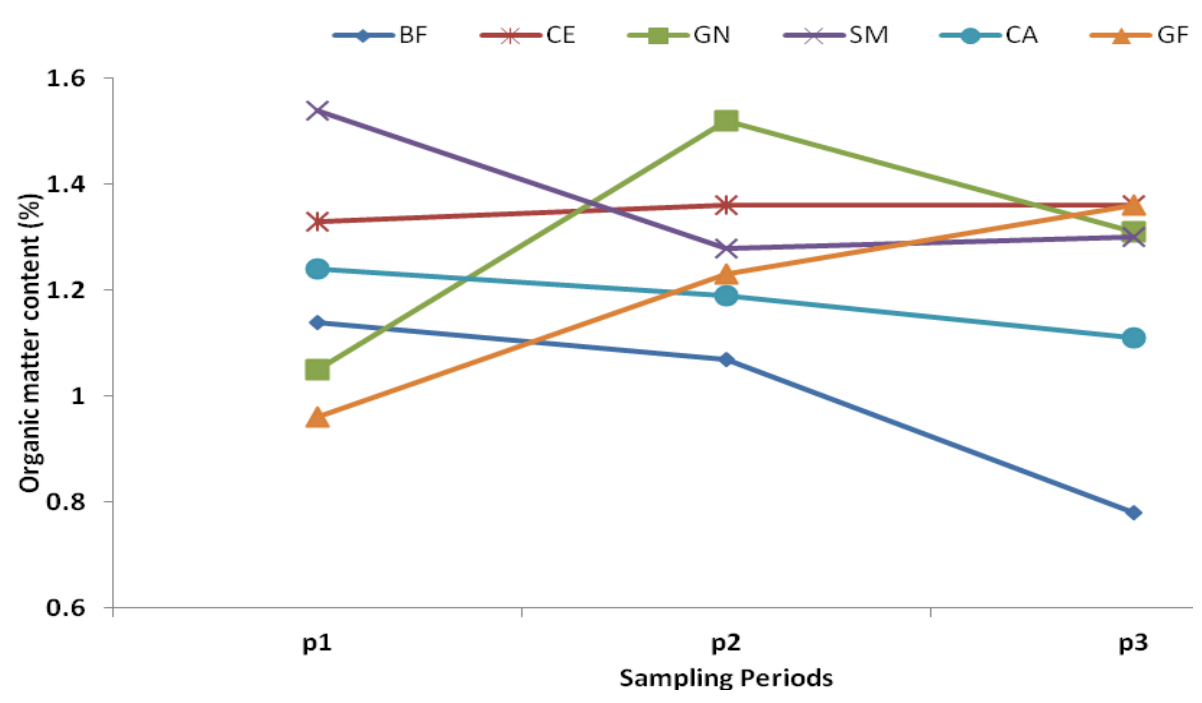

Figure 1: Variations in Organic matter content over three sampling periods under different

P1 = end of first cropping season (October, 2010).

P2 = start of second/ new cropping (March, 2011).

P3 = end of second cropping season (September, 2011).

Table 1: The texture and organic matter content of the surface soil $(0-20 \mathrm{~cm})$ at the start of the experiment in 2010

\begin{tabular}{llllll}
\hline Management practices & Sand $(\%)$ & Silt $(\%)$ & Clay $(\%)$ & Textural Class & $\begin{array}{l}\text { O.M. } \\
(\%)\end{array}$ \\
\hline BF & 76 & 8 & 16 & SL & 1.21 \\
CE & 78 & 7 & 15 & SL & 1.46 \\
GN & 74 & 9 & 17 & SL & 1.06 \\
SM & 76 & 9 & 15 & SL & 0.87 \\
CA & 79 & 9 & 15 & SL & 1.13 \\
GF & 75 & 9 & 16 & SL & 1.34 \\
\hline O.M. = Organic matter, SL= Sandy loam & & &
\end{tabular}


Azuka C.V. and Obi M.E.

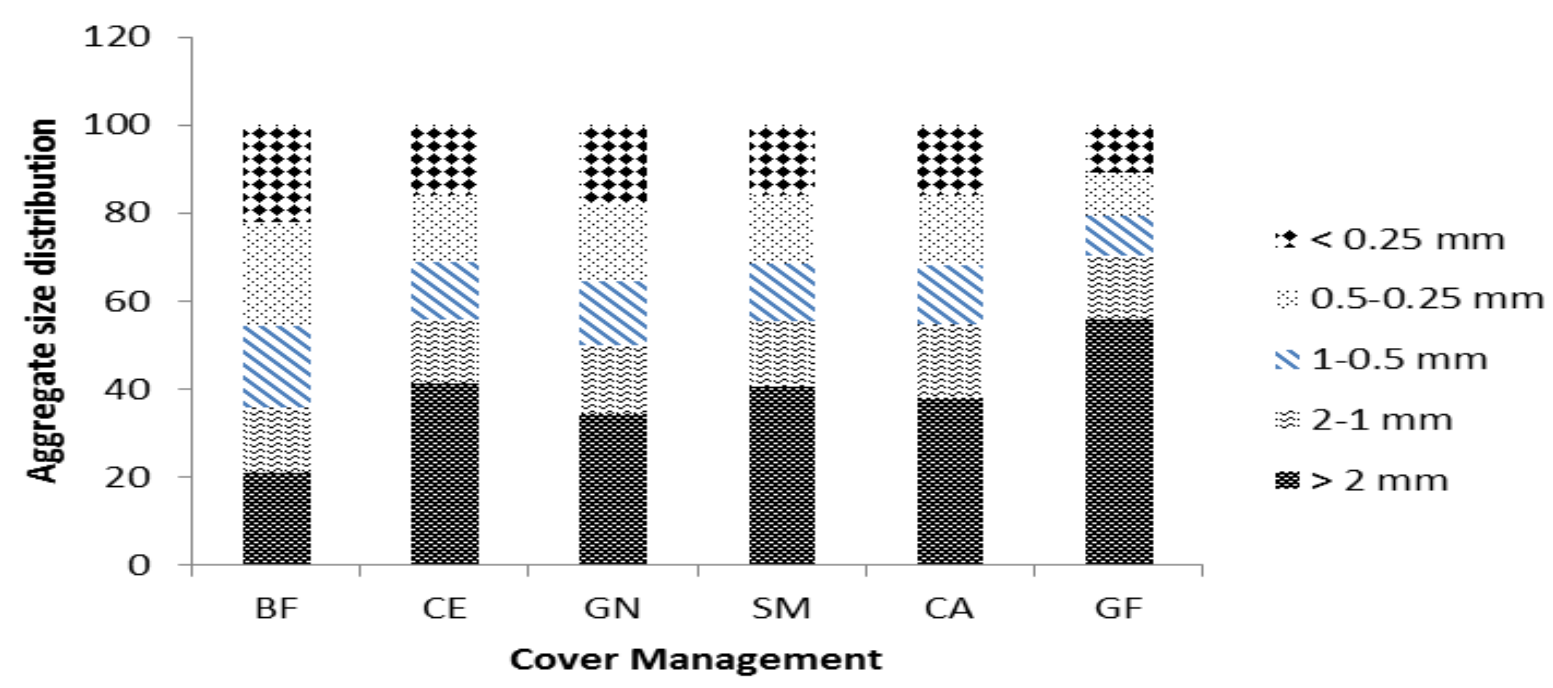

Fig 2 Aggregate size distribution under different cover management practices

\section{Table 2: The texture and organic matter content of the surface soil $(0-20 \mathrm{~cm})$ at the end of the experiment in 2011.}

\begin{tabular}{lllllll}
\hline Management practices & Sand $(\%)$ & Silt $(\%)$ & Clay $(\%)$ & Textural Class & O.M. & $(\%)$ \\
\hline BF & 73 & 7 & 20 & SL & 0.78 & \\
CE & 75 & 8 & 17 & SL & 1.36 & \\
GN & 75 & 8 & 17 & SL & 1.31 & \\
SM & 77 & 7 & 16 & SL & 1.31 \\
CA & 76 & 7 & 17 & SL & 1.11 \\
GF & 76 & 7 & 17 & SL & 1.36 & \\
\hline
\end{tabular}

O.M. = Organic matter, $\mathrm{SL}=$ Sandy loam

\section{Saturated hydraulic conductivity (Ksat)}

The saturated hydraulic conductivity of the soil under different cover management practices over the three sampling periods is shown in Fig 3. The highest mean value $(16.1 \mathrm{~cm} / \mathrm{hr})$ was obtained at the end of the first cropping season whereas the least value $(7.01 \mathrm{~cm} / \mathrm{hr})$ was obtained at the end of the second cropping season (Table 4). Nimmo et al., (2002) reported that soils after initial tillage quickly revert back to their original state and sometimes becomes more compacted compared to their initial state. The values of Ksat decreased by almost $30-50 \%$ between the first and last sampling periods. Ksat was low under the grass fallow whereas that of the bare fallow was the lowest throughout the sampling periods as a result of no tillage together with the exposure to raindrops that break large clods or macroaggregates into fine particles or microaggregates. These fine particles block the soil pores and reduce the number of available pores open for hydraulic flows. The various cover management practices had significant effect $(\mathrm{p}=0.05)$ on Ksat (Table 3). Ksat varied significantly $(P=0.05)$ due to cover management with a SD of 7.8 and a CV of $52 \%$. The highest value $(16.67 \mathrm{~cm} / \mathrm{hr})$ was obtained under $\mathrm{GN}$ whereas the lowest value $(5.18 \mathrm{~cm} / \mathrm{hr})$ was obtained under $\mathrm{BF}$. The effect of various cover management practices on Ksat follow the trend Groundnut >centrosema > Grass $=$ Bare.

\section{Correlation of organic matter content and selected soil physical parameters}

Organic matter had a significant negative correlation $(P=0.05)$ with two aggregate size ranges $(1-0.5 \mathrm{~mm}$ and $0.5-0.25 \mathrm{~mm}$ ) (Table 5). This implies that organic matter plays little or no role in stabilizing these aggregates against what had been obtained in other studies. Six et al., (2002) hypothesized that WSA formation should be more independent from organic matter inputs in tropical soils than in temperate soils. Six et al (2002) also found lower correlation between organic carbon with aggregate stability and attributed the high aggregate stability of the location to the soil mineralogy dominated by $1: 1$ clay minerals and oxides in tropical regions. 


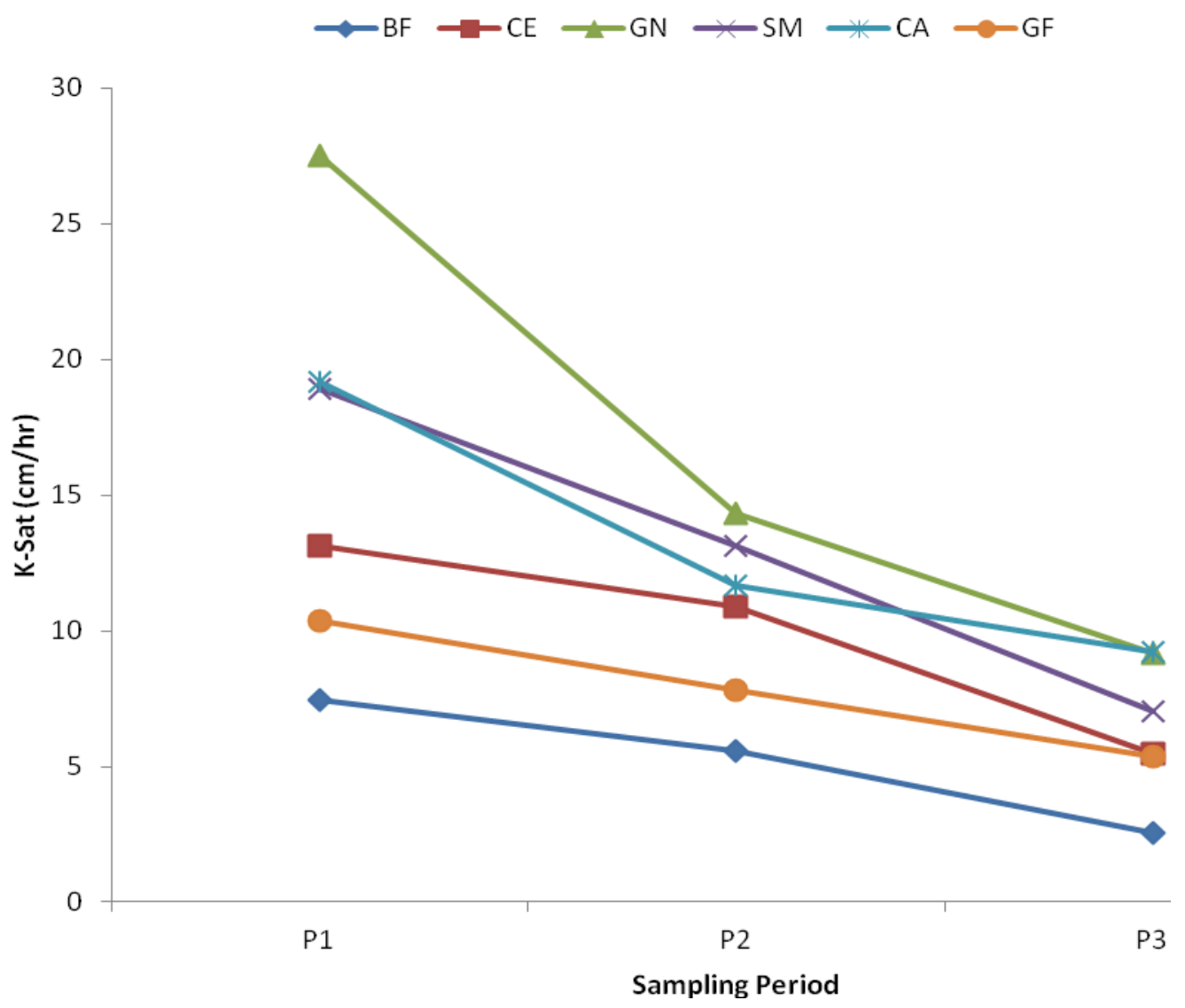

Fig 3: Variation in saturated hydraulic conductivity (Ksat) over three sampling period under different cover management

$\mathrm{P} 1=$ end of first cropping season (October, 2010).

P2 = start of second/ new cropping (March, 2011).

P3 = end of second cropping season (September, 2011).

Table 3: Mean values of aggregate size distribution and soil structural properties under the influence of different cover management practices.

\begin{tabular}{|c|c|c|c|c|c|c|c|c|c|c|c|}
\hline \multirow{2}{*}{$\begin{array}{l}\text { Cover } \\
\text { mgt }\end{array}$} & \multicolumn{4}{|c|}{ Percentage of aggregate sizes } & \multirow[b]{2}{*}{$<0.25$} & \multirow{2}{*}{$\begin{array}{l}\text { MWD } \\
(\mathrm{mm})\end{array}$} & \multirow{2}{*}{$\begin{array}{l}\text { O.M. } \\
(\%)\end{array}$} & \multirow[t]{2}{*}{ AS (\%) } & \multirow[t]{2}{*}{ WDC } & \multirow[t]{2}{*}{ WDSi } & \multirow{2}{*}{$\begin{array}{l}\text { K-sat } \\
(\mathrm{cm} / \mathrm{hr})\end{array}$} \\
\hline & $>2.00$ & 2- 1 & $1-0.5$ & $0.5-0.25$ & & & & & & & \\
\hline $\mathrm{BF}$ & 20.9 & 14.8 & 18.5 & 23.57 & 22.17 & 1.18 & 0.998 & 51.2 & 6.32 & 5.28 & 5.18 \\
\hline CE & 41.1 & 14.7 & 12.9 & 15.56 & 5.81 & 1.78 & 1.349 & 69.5 & 6.32 & 5.28 & 11.17 \\
\hline GN & 34.4 & 15.4 & 14.5 & 17.74 & 17.96 & 1.59 & 1.295 & 66.2 & 6.65 & 5.11 & 16.76 \\
\hline SM & 40.4 & 15.1 & 12.8 & 15.68 & 15.97 & 1.76 & 1.375 & 69.1 & 6.99 & 4.45 & 13.04 \\
\hline $\mathrm{CA}$ & 37.8 & 16.8 & 13.5 & 15.94 & 16.15 & 1.71 & 1.179 & 69.2 & 6.99 & 3.95 & 13.34 \\
\hline GF & 55.6 & 14.6 & 9.11 & 9.78 & 10.90 & 2.22 & 1.185 & 80.3 & 6.65 & 4.28 & 7.85 \\
\hline CV (\%) & 30.9 & 21.8 & 23.0 & 27.2 & 27.1 & 20.2 & 15.0 & 13.4 & 19.8 & 30.8 & 52.8 \\
\hline SD & 1.56 & 3.51 & 4.17 & 5.93 & 5.67 & 0.46 & 0.24 & 16.0 & 1.23 & 1.59 & 7.80 \\
\hline $\mathrm{LSD}_{0.05}$ & 9.72 & ns & 2.55 & 3.65 & 3.66 & 0.28 & 0.15 & 7.41 & ns & ns & 4.85 \\
\hline
\end{tabular}

AS = aggregate stability, WDC $=$ water dispersible clay, WDSi $=$ water dispersible silt, $\mathrm{K}$-sat $=$ saturated hydraulic conductivity, MWD = mean weight diameter, $\mathrm{CV}=$ coefficient of variation, $\mathrm{SD}=$ standard deviation, $\mathrm{LSD}=$ least significant difference at $5 \%$ probability level, $\mathrm{ns}$ $=$ not significant 
Table 4: Combine effect of sampling period and cover management practices on aggregate size distribution and soil structural properties

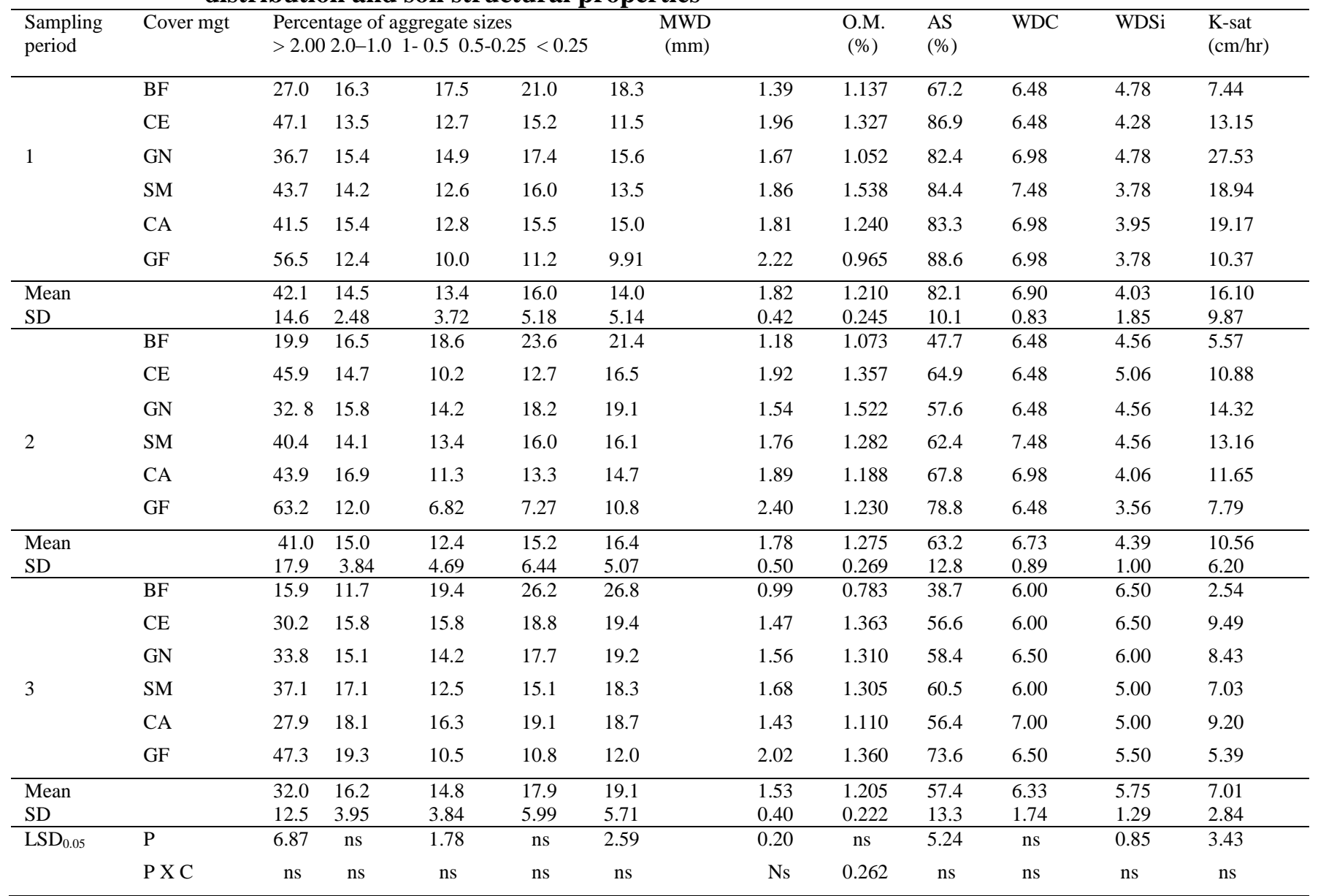

Table 5: Correlation of organic matter content and selected soil physical parameters

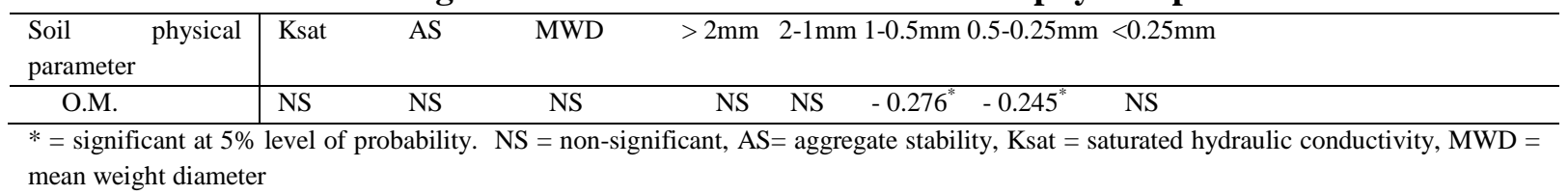

\section{CONCLUSIONS}

The study assessed the effects of cover management practices at three sampling periods on the selected surface $(0-20 \mathrm{~cm})$ soil properties of a sandy loam soil in Southeastern Nigeria. Aggregate stability, MWD and Ksat changes with the sampling periods. The OM content was low throughout the sampling periods. The various cover management practices had significant effect on the soil properties determined throughout the sampling dates. The aggregate stability, MWD, aggregate size distribution and Ksat varied from one period to another and are influenced differently by different crops. Therefore, appropriate management practice should be designed for each crop to prevent further degradation and ensure sustainable productivity of this soil. Crops that degrade these soil properties should either be intercropped or subsequently be planted in rotation with those that improved these soil properties.

\section{REFERENCES}

Amezkeka, E. (1999). Soil aggregate stability: a review. Journal of Sustainable Agriculture 14, 8151.

Bronick, C.J. and Lal, R. (2005): Soil structure and management: a review. Geoderma, 124: 322.

Cantón, Y., Solé-Benet, A., Asensio, C., Chamizo, S. and Puigdefábregas, J., (2009). Aggregate 
stability in range sandy loam soils Relationships with runoff and erosion. Catena 77 (2009) 192-199

Chan, K.Y., Heenan, D.P. and Ashley, R. (1994). Seasonal changes in surface aggregate stability under different tillage and crops. Soil and Tillage Research 28, 301-314.

Estela, B. (2003). Structure and Organic Matter under Different Soil Management Conditions in the Center of Argentina. Lecture given at the College on Soil Physics Trieste, 3 -21 March 2003

Farella, N., Cucotte, M., Louchouarn, P. and M. Roulet. (2001) Deforestation modifying terrestrial organic transport in the Pio Tapajos, Brazilian Amazon. Org. Gecohem., 32: 1443-1458.

Gee, G.W. and Bauder, J.W. (1986). Particle size analysis. In: methods of soil analysis part I. klute, A (Ed.). monograph no. 9, Am. Soc. Agron. Madison, WI, pp: $91-100$.

GENSTAT (2003). GENSTAT 5.0 Release 4.23 DE, Discovery Edition 1, Lawes Agricultural Trust Rothamsted experimental station press, UK.

Kemper, W.D. and Rosenau, R.C. (1986). Size distribution of aggregates. In: method of soil analysis, A. Klute (Ed.). part I. $2^{\text {nd }}$ Edn, Agron. Monogr. 9 ASA-SSSA, Madison, WI. pp: $425-442$.

Maineville, N., Webb, J., Lucotte, M., Davidson, R., Betancourt,O., Cueva, E. and Mergler, D.(2006).

Decrease in soil fertility and release of mercury following deforestation in the Andean Amazon, Napo River valley, Ecuador. Sci. Total Environ., 368:88-98.

Mbagwu,J.S.C., 2003. Aggregate stability and soil degradation in the tropics .Paper presented at 2003 .College on soil physics ICTP Triete Italy.

Messing, I. and Jarvis, N.J. (1993). Temporal variation in the hydraulic conductivity of a tiled clay soil as measured by tension infiltrometers. Journal of Soil Science 44, 11-24.

Murphy, B.W., Koen, T.B., Jones, B.A. and Huxedurp, L.M .(1993).Temporal variation of hydraulic properties for some soils with fragile structure. Australian Journal of Soil Research 31, 179-197.
Nelson, D.W. and I.E. Sommers (1982). Total carbon and organic matter. In: methods of soil analysis part II, page, A.L. (Ed). chemical and microbiological properties. Am. Soc. Agron. Madison, WI., pp 359-586.

Nimmo, J.R.(2004). Aggregation : physical aspects. US. Geological Survey, Menlo Park, USA.

Nwadialo, B.E. (1989). Soil landscape relationship in the Udi-Nsukka plateau. Catena 16:111120.

Obi, M. E., 1982. Runoff and soil from an oxisol in southeastern Nigeria under various management practices. Agric water manage., 5: 193-203.

Obi, I.U., (2002). Statistical Methods of Detecting Differences between Means and Research Methodology Issues in Laboratory and Field Experiments (2nd ed.). Enugu: Snaap Press (Nig.) Ltd. 117 pp

Obi, M. E. and P.C Nnabude, 1988. The effect of different management practices on the physical properties on a sandy loam soil in southern Nigeria. Soil and Tillage Research. 12:81-90.

Oti, N.N. (2002). Discriminant functions for classifying erosion degraded lands at Otamiri, Southeastern Nigeria. Agro-Sci 3 (1): 34-40.

Piccolo, A., Fietramellara, G. and Mbagwu, J.S.C (1997). Reduction in soil loss from erosion susceptible soils amended with humic substances from oxidized coal. Soil Technology 10; 235245.

Sierra, R. 2000. Dynamics and patterns of deforestation in the Western Amazon: The Napo deforestation front, 1986-1996. Appl. Geogr., 20: 1-16.

Six, J., Feller, C., Denef, K., Ogle, S.M. (2002): Soil organic matter, biota and aggregation in temperate and tropical soils - Effect of notillage. Agronomie, 22: 755-775.

Somaratne, N.M. and Smettem, K.R.J .(1993) Effect of cultivation and raindrop impact on the surface hydraulic properties of an alfisol under wheat. Soil and Tillage Research 26, 115-125. 
Strudley, W.M., Green, T.R. and Ascough, I.J.C. (2008) Tillage effects on soil hydraulic properties in space and time: State of the science. Soil and Tillage Research 99, 4-48.

Veronika, J., Radka, K., Marcela, M. and Anna, Z. (2010). Seasonal variability of soil structure and soil hydraulic properties. $19^{\text {th }}$ world congress of Soil Science, Brisbane Australia, P: $1-4$.
Youngs, E.G. (2001). Hydraulic conductivity of saturated soils. In; Soil and Environmental Analysis. Smith, K.A. and C.E. Mullins (Eds.). Physical Methods. $2^{\text {nd }}$ Edn. Marcel Decker Inc. NY., pp. 637.

Yang X.M. and Wander M.M. (1998) Temporal changes in dry aggregate size and stability. Soil and Tillage Research 49, 173-183. 